Research Article

\title{
The Role of $\beta$-Catenin in Th1 Immune Response against Tuberculosis and Profiles of Expression in Patients with Pulmonary Tuberculosis
}

\author{
Kunlong Xiong, ${ }^{1}$ Jinxia Niu, ${ }^{1}$ Ruijuan Zheng, ${ }^{1}$ Zhonghua Liu, ${ }^{1}$ Yanzheng Song, ${ }^{2}$ \\ Lin Wang $\mathbb{D}^{2}$, Changtai Zhu $\mathbb{D}^{3},^{3}$ and Lin Fan $\mathbb{D i D}^{1}$ \\ ${ }^{1}$ Shanghai Clinical Research Center for Tuberculosis, Shanghai Key Lab of Tuberculosis, Shanghai Pulmonary Hospital, \\ Tongji University School of Medicine, Shanghai, China \\ ${ }^{2}$ Shanghai Public Health Clinical Center, Shanghai, China \\ ${ }^{3}$ Department of Laboratory Medicine, Shanghai Jiao Tong University Affiliated Sixth People's Hospital, Shanghai, China
}

Correspondence should be addressed to Lin Wang; wlxxs2011@163.com, Changtai Zhu; zct101@163.com, and Lin Fan; fanlinsj@163.com

Received 3 November 2020; Revised 10 January 2021; Accepted 23 January 2021; Published 11 February 2021

Academic Editor: M. Victoria Delpino

Copyright $\odot 2021$ Kunlong Xiong et al. This is an open access article distributed under the Creative Commons Attribution License, which permits unrestricted use, distribution, and reproduction in any medium, provided the original work is properly cited.

$\beta$-Catenin is a key molecule of canonical $\mathrm{Wnt} / \beta$-catenin pathway. Its roles and expression profiles in $\mathrm{T}$ cells of tuberculosis (TB) remain unclear. The aim of this study was to explore the role of $\beta$-catenin in CD4 ${ }^{+} \mathrm{T}$ cells and its expression characteristics in patients with pulmonary tuberculosis (PTB). In this study, CD4 ${ }^{+} \mathrm{T}$ cell-specific $\beta$-catenin conditional knockout mice $(\beta$-CATcKO mice) were aerosol infected with Mycobacteria tuberculosis $(M t b) \mathrm{H}_{37} \mathrm{R}_{\mathrm{V}}$ with wild-type mice as controls. Four weeks after infection, the mRNA expression of IFN- $\gamma$, TNF- $\alpha$, and TCF-7 in the lungs of mice was measured. CD4, CD8, $\beta$-catenin, IFN- $\gamma$, and TNF- $\alpha$ in mononuclear cells from the lungs and spleens were measured by flow cytometry, and the pathological changes of lungs were also observed. Patients with PTB were enrolled, with blood samples collected and PBMCs isolated. The expressions of $\beta$-catenin, IFN- $\gamma$, TNF- $\alpha$, and PD- 1 in $\mathrm{CD}^{+}$and $\mathrm{CD}^{+}$T cells were measured by flow cytometry. Results showed a decreased frequency of and reduced IFN- $\gamma / \mathrm{TNF}-\alpha$ mRNA expression and secretion by CD $4^{+} \mathrm{T}$ cells in the lungs of infected $\beta$-CAT-cKO mice compared with infected wild-type controls, and only slightly more inflammatory changes were observed in the lungs. $\beta$ catenin expressions in $\mathrm{CD}^{+}$and $\mathrm{CD} 8^{+} \mathrm{T}$ cells were significantly decreased in blood cells of patients with severe PTB compared with those in mild PTB. The stimulation of peripheral blood mononuclear cells (PBMCs) with lithium chloride (LiCl), a stimulant of $\beta$-catenin, resulted in the increase in $\mathrm{CD} 4^{+} \mathrm{T}$ cell frequency, as well as their secretion of IFN- $\gamma$ and TNF- $\alpha$. $\beta$ Catenin demonstrated a moderately positive correlation with PD- 1 in CD4 ${ }^{+}$T cells. $\beta$-Catenin along with PD- 1 and IFN- $\gamma$ in $\mathrm{CD}^{+} \mathrm{T}$ cells had a high correlation with those in $\mathrm{CD}^{+} \mathrm{T}$ cells. In conclusion, $\beta$-catenin may be involved in the regulation of $\mathrm{Th} 1$ response and $\mathrm{CD} 4^{+} \mathrm{T}$ cell frequency in $\mathrm{TB}$

\section{Introduction}

Tuberculosis (TB) remains one of the main global causes of morbidity and mortality as an infectious disease. However, the immune response and its regulation mechanism in the host have not yet been cleared. $\beta$-Catenin is a key molecular of canonical Wnt/ $\beta$-catenin pathway which is involved in the control of cell proliferation, differentiation, and differentiation in embryonic development [1]; $\mathrm{CD}^{+}{ }^{+} \mathrm{T}$ cells play essential roles in controlling $\mathrm{TB}$, and $\mathrm{CD}^{+} \mathrm{T}$ cells exhibit protection function against $\mathrm{TB}$ as well [2]. $\beta$-Catenin can regulate the $\mathrm{T}$ cell factor 1 (TCF1) in TCR signaling for differentiation of $\mathrm{CD}^{+}{ }^{+} \mathrm{T}$ cells [3]. TCF1 or stabilized $\beta$-catenin can greatly stimulate the expression of the $\mathrm{CD} 4$ reporter gene by $\mathrm{CD} 4$ enhancer and promoter [4].

In the studies of $\beta$-catenin-related diseases, numerous published studies associate $\beta$-catenin, as a candidate antitumor therapeutic target, with the pathogenic process of 
Table 1: Primers used for identification.

\begin{tabular}{lcc}
\hline Gene & Sequence $5^{\prime} \rightarrow 3^{\prime}$ & Reaction \\
\hline & GTTCTTTGTATATATTGAATGTTAGCC & Common \\
CD4-Cre & TATGCTCTAGGACAAGAATTGACA & Wild-type reverse \\
& CTTTGCAGAGGGCTAACAGC & Mutant reverse \\
Ctnnb1 & AAGGTAGAGTGATGAAAGTTGTT & Forward \\
& CCTGTTAGCCCTCATGGTGT & Reverse \\
\hline
\end{tabular}

malignant diseases by the regulation of cell differentiation [5-8]. Other studies indicated that $\mathrm{Wnt} / \beta$-catenin signaling plays a role in the immune regulation of infectious diseases $[1,9]$. Wnt/ $\beta$-catenin canonical pathway could exhibit its regulation function in innate immunity against TB [1]. It is reported Wnt $/ \beta$-catenin signaling could inhibit Bacillus Calmette-Guerin- (BCG-) infected macrophage autophagy and necrosis $[10,11]$. Wnt $/ \beta$-catenin is able to promote mitochondria-dependent apoptosis pathway in BCGinfected macrophage $[10,12]$.

CTNNB1 gene has been shown to have gene polymorphisms of tuberculosis susceptibility in the Chinese Tibetan population [13]. Our previous studies [14] showed impaired IFN- $\gamma$ expression and decreased $\mathrm{CD} 4^{+} \mathrm{T}$ cells in the blood of patients with severe cavitary PTB. A further study [15] indicated that $\beta$-catenin might be involved in the impaired IFN- $\gamma$ expression, Th1 immune response of the host against TB, and mRNA of $\beta$-catenin, and TCF-7 was impaired in the CD14 cells in the blood of patients with severe cavitary PTB.

In the present study, the role of $\beta$-catenin in the immunological regulation of $\mathrm{CD} 4^{+} \mathrm{T}$ cells was further explored. We constructed the $\mathrm{CD}^{+}{ }^{+} \mathrm{T}$ cell-specific Ctnnb1 conditional knockout mice and infected the mice with $M t b \mathrm{H} 37 \mathrm{Rv}$ through aerosol infection. Then, patients with active PTB were enrolled to determine the expression profiles of $\beta$ catenin and its related cytokines in human blood.

\section{Materials and Methods}

2.1. Patients. The patients hospitalized were recruited and satisfied the included criteria; the blood samples were collected from August 1, 2018, to March 31, 2019, at Shanghai Pulmonary Hospital, Tongji University. The included criteria were as follows: patients were confirmed as having active pulmonary tuberculosis (PTB) with $M t b$ culture positive or sputum acid-fast bacilli (AFB) smear positive with typical radiological changes consistent with $\mathrm{TB}$ manifestation or PCR amplification of $M t b$ positive. All patients included could be classified into severe lesion PTB and mild lesion PTB and had not been previously treated by anti-TB chemotherapy or been treated within one week. The method of classification was decided on the radiological manifestation and clinical characteristics previously described in our previous studies $[14,15]$. Severe lesion PTB was defined as patients with a cavity of $\geq 3 \mathrm{~cm}$ in diameter or more than 3 cavities regardless of the diameter of the cavity; mild lesion PTB was defined as patients with no cavity of lesions in $\leq 2$ lung fields. The study got the approval of the ethical committee of Shanghai Pulmonary Hospital; the approval number was fk17-022. All included patients signed the informed consent to participate in the study.

Patients who were in immunosuppressive status (including serum HIV-positive subjects) or were using immunosuppressive agents and accompanied by severe complications such as diabetes mellitus, malignant diseases, and liver diseases were excluded from this study.

2.2. Mice and Mtb Infection. All mice used in this study have C57BL/ 6 genetic background. $\beta$-CAT-cKO mice were generated by breeding mice bearing a LoxP-flanked gene Ctnnb1 $\left(C_{n n n} 1^{\text {flox/flox }}\right.$ ) with CD4-Cre mice (mice expressing Cre recombinase under the control by $\mathrm{CD} 4$ promoter). Both $C t n n b 1^{\text {flox/flox }}$ and CD4-Cre mice were provided by Jackson Laboratory. To generate CD4-Cre/Ctnnb $1^{\text {flox fllox }}$ mice, homozygous Ctnnb1 $1^{\text {flox/flox }}$ mice were bred with $\mathrm{CD} 4$-Cre mice, and then, the offspring with genotype CD4-Cre ${ }^{+/-} / \mathrm{Ctnn}_{n} \mathrm{I}^{+/-}$ flox were intercrossed. The genotype was identified by PCR. Genomic DNA was prepared following standard tail clipping and DNA extraction procedures. PCR products were loaded in $2.5 \%$ agarose gel dyed with ethidium bromide for band visualization, and the primers used are listed in Table 1. All mice were bred in specific pathogen-free conditions at the Shanghai Model Organisms Center, Inc. Mice (6-8 weeks old) were divided randomly into cages upon arrival and infected by the nasal dropping of $5 \times 10^{4} \mathrm{cfu} M t b(\mathrm{H} 37 \mathrm{Rv})$ in the Biosafety Level-3 (BSL-3) Laboratory. The agematched wild-type littermates were used as controls. All mice experiments were performed in accordance with the University Health Guide for the Care and Use of Laboratory Animals and were approved by the Ethics Committee of Shanghai Pulmonary Hospital.

2.3. Bacteria. $\mathrm{M} t b \mathrm{H} 37 \mathrm{Rv}$ were grown in Middlebrook $7 \mathrm{H} 9$ broth (BectonDickinson, Cockeysville, MD) with 0.05\% Tween- 80 and $10 \%$ oleic acid-albumin-dextrose-catalase (OADC) (BectonDickinson, Cockeysville, MD).

2.4. Preparation of Single-Cell Suspension and Flow Cytometry. Mice were sacrificed by cervical dislocation at 28 days after infection. The lungs and spleens were collected and cut with scissors, then digested by pancreatin at $37^{\circ} \mathrm{C}$ with continuous agitation for 1 hour in a temperaturecontrolled water bath. After digestion, digested tissues were filtered through a sheet of mesh $(70 \mu \mathrm{m})$ screen into a $15 \mathrm{ml}$ centrifuge tube for single-cell suspension; the tissues left were homogenized by grinding and also filtered into the $15 \mathrm{ml}$ centrifuge tube. After washed by $1 \mathrm{ml}$ RPMI-1640 (Gibco Invitrogen, Carlsbad, USA), the cells were resuspended with 
TABle 2: Primers used for qPCR.

\begin{tabular}{lcc}
\hline Gene & Forward primer $\left(5^{\prime} \rightarrow 3^{\prime}\right)$ & Reverse $\operatorname{primer}\left(5^{\prime} \rightarrow 3^{\prime}\right)$ \\
\hline$T c f-7$ & AAGAAGAAGAGGCGGTCAAGG & CACTGTCATCGGAAGGAACG \\
$I f n-\gamma$ & TCAAGTGGCATAGATGTGGAAGA & TGCTGATGGCCTGATTGTCT \\
$T n f-\alpha$ & ACTGGCAGAAGAGGCACTCC & GCCACAAGCAGGAATGAGAA \\
Actb & CCCAGTCCTTCACGCAAGAG & CATCTAGCGTCTCAGGGAACA \\
\hline
\end{tabular}

TABLE 3: Characteristics of patients with PTB.

\begin{tabular}{lccc}
\hline Characteristics & Severe PTB (17) & Mild PTB (22) & $p$ value \\
\hline Age & $30.7 \pm 12.5$ & $38.8 \pm 13.3$ & 0.62 \\
Sex (male) & $9(52.9 \%)$ & $13(59.1 \%)$ & 0.701 \\
HIV positive & 0 & 0 & - \\
Accompanied by DM & 0 & 0 & - \\
Taking immune-suppressive agents & 0 & 0 & - \\
Malignant diseases & 0 & $7(31.8 \%)$ & 0.82 \\
Smoking & $6(35.3 \%)$ & $3(13.6 \%)$ & 0.86 \\
Alcohol & $2(11.7 \%)$ & $5(22.7 \%)$ & 0.697 \\
Concurrent EPTB & $3(17.6 \%)$ &
\end{tabular}

PTB: pulmonary tuberculosis; EPTB: extrapulmonary tuberculosis; DM: diabetes mellitus.

RPMI-1640 (supplemented with $10 \%$ calf serum, $100 \mathrm{U} / \mathrm{l}$ penicillin, and $100 \mathrm{U} / 1$ streptomycin) and diluted to $5 \times 10^{6}$ cells $/ \mathrm{ml}$.

The isolated single-cell suspension was incubated at $37^{\circ} \mathrm{C}$ in a $5 \% \mathrm{CO}_{2}$ incubator with $1 \mu \mathrm{l} / \mathrm{ml}$ Brefeldin $\mathrm{A}(\mathrm{BFA}, \mathrm{BD})$ for 5 hours. Then, cells were washed with RPMI-1640 and resuspended in flow cytometry staining buffer for surface marker staining. The cells were incubated with antimouse CD3-Pacific Blue (Clone 17A2, BioLegend) (1:200), CD4BV510 (Clone RM4-5, BD Horizon $\left.{ }^{\mathrm{TM}}\right)(1: 200)$, and CD69BV605 (Clone H1.2F3, BioLegend) $(1: 100)$ antibodies for 30 minutes in the dark at $4^{\circ} \mathrm{C}$. After surface marker staining, cells were permeabilized with fixation/permeabilization buffer (Transcription Factor Buffer Set, BD Pharmingen ${ }^{\mathrm{TM}}$ ) for 40 minutes at $4^{\circ} \mathrm{C}$, then incubated with antimouse IFN$\gamma$-BV711 (Clone XMG1.2, BD Horizon ${ }^{\mathrm{TM}}$ ) $(1: 100), \beta$ catenin-Alexa 488 (Clone 14/Beta-Catenin, BD Transduction Laboratories $\left.^{\mathrm{TM}}\right)(1: 100)$ and TNF- $\alpha$-PE-Cy7 (Clone MP6XT22, BioLegend) $(1: 100)$ antibodies for 30 minutes in the dark at $4^{\circ} \mathrm{C}$ for intracellular cytokines staining; then, cells were washed by perm/wash buffer (included in Transcription Factor Buffer Set).

On account, $\beta$-catenin is a nuclear transcription factor, which expresses in both the cell cytoplasm and nucleus. Transcription Factor Buffer Set was used in this study for intracytoplasmic and intranuclear staining of $\beta$-catenin.

BD Canto II flow cytometer (BD Biosciences) was used to analyze the expression of surface markers and intracellular cytokines, and at least 10,000 events were collected. The results were analyzed using the FlowJo version 10.0.7 software (Tree Star, Ashland, OR, USA).

2.5. Histological Analysis. Following fixation with $4 \%$ phosphate-buffered formalin for $24 \mathrm{~h}$, the lung tissues from
$M t b$-infected mice were embedded in paraffin wax and were cut into serial sections of 2-3 $\mu \mathrm{m}$ thickness. The infiltration of immune cells into the lungs was detected by haematoxylin and eosin (H\&E) staining.

2.6. RT-PCR Analysis. RNA from lungs and spleens of mice was extracted using TRIzol reagent (Invitrogen, Carlsbad, CA, USA). We performed cDNA synthesis using ReverTra Ace $^{\circledR}$ qPCR RT kits (FSQ-101, Toyobo), and the relative mRNA expression of different genes was measured by quantitative real-time PCR with $\mathrm{SYBR}^{\circledR}$ Green Realtime PCR Master Mix kits (QPK-212, Toyobo) and calculated by comparison with the control gene $A c t b$ (encoding $\beta$-actin) using the $2^{-\Delta \mathrm{Ct}}$ method. The primers used are listed in Table 2.

2.7. Isolation of PBMCs. The included patients and healthy volunteers donated venous blood samples $(10 \mathrm{ml})$ in heparin tubes; PBMCs (peripheral blood mononuclear cells) were isolated within six hours after drawn. PBMCs' isolation was performed by density gradient centrifugation using FicollPaque Plus (GE healthcare, UK) following the manufacturer's instructions.

2.8. Human Cell Staining and Flow Cytometry. PBMCs were incubated at $37^{\circ} \mathrm{C}$ in a $5 \% \mathrm{CO}_{2}$ incubator, and BFA $(1 \mu \mathrm{l} / \mathrm{ml})$ was added to the cells 5 hours before staining. Antibodies were prepared, cells transferred to tubes then spun down at $350 \mathrm{~g}$ for 5 minutes at $4^{\circ} \mathrm{C}$, and washed once in $500 \mu \mathrm{l} \mathrm{FACS}$ buffer. Samples were resuspended in $100 \mu \mathrm{l}$ of diluted antibody against human cell-surface markers APC/H7-conjugated antihuman CD3 (Clone SK7, BD Pharmingen ${ }^{\mathrm{TM}}$ ) (1:200), BB515-conjugated antihuman CD4 (Clone PRAT4, BD Horizon $\left.{ }^{\mathrm{TM}}\right)(1: 200)$, and APC-conjugated antihuman CD279 (clone MIH4, BD Pharmingen $\left.{ }^{\mathrm{TM}}\right)(1: 100)$; incubated for 30 minutes at $4^{\circ} \mathrm{C}$; and washed twice in $500 \mu \mathrm{l} \mathrm{FACS}$ 


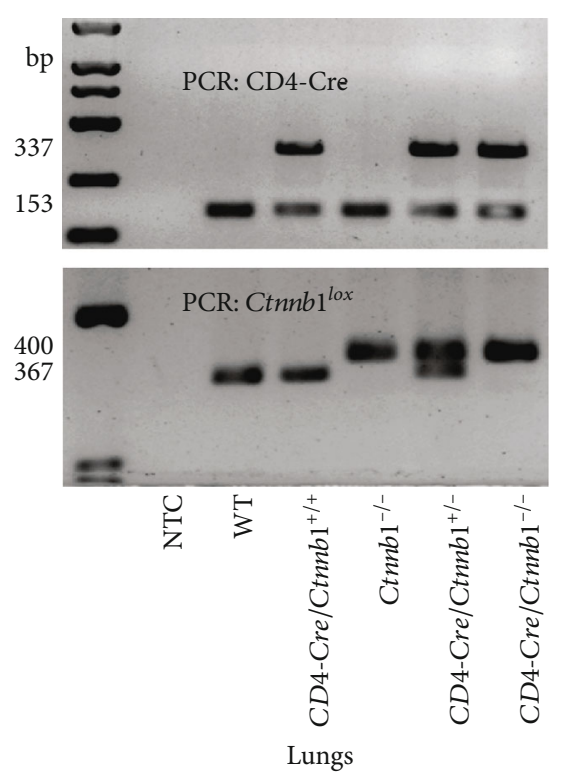

(a)

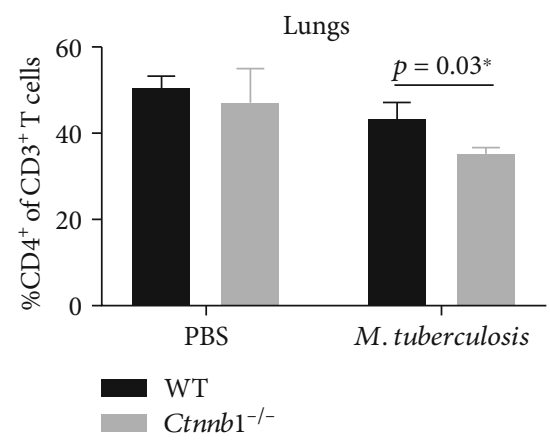

(c)

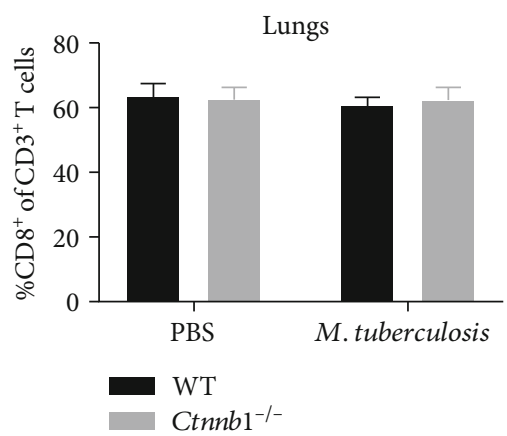

(e)

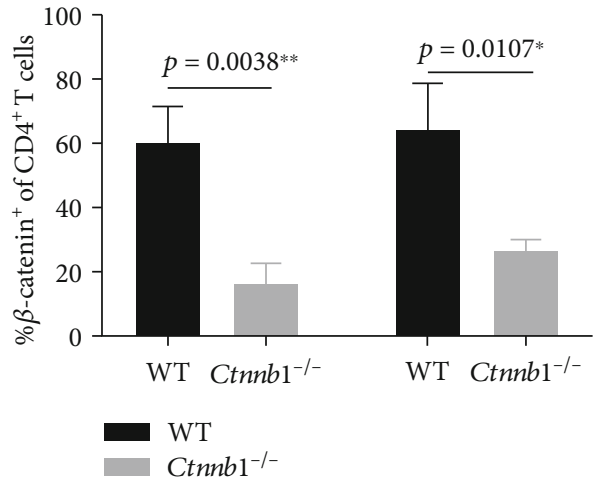

(b)

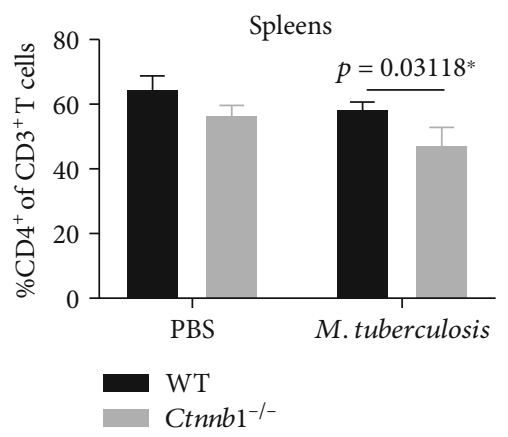

(d)

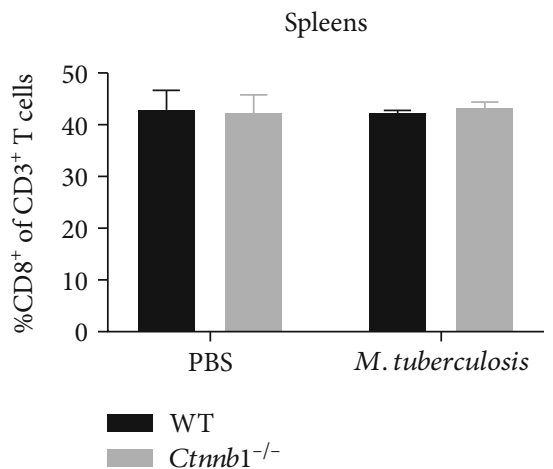

(f)

FIGURE 1: The genotypes of all mice identified by PCR and T cells frequency in both groups of mice by flow cytometry. (a) Mice's genotypes were identified by PCR, and results were showed by $2.5 \%$ agarose gel electrophoresis. (b) The frequency of $\beta$-catenin ${ }^{+}$cells of CD $4^{+} \mathrm{T}$ cells in lungs and spleens of $\mathrm{Ctnnb1}^{-1-}$ mice $(n=5)$ and wild-type mice $(n=5) ; \mathrm{CD}^{+} \mathrm{CD} 4^{+} \mathrm{T}$ cells were shown in the lungs (c) and spleens (d) of Ctnnb1 $1^{--}(n=5)$ and wild-type mice $(n=5)$ infected with or without M. tuberculosis; $\mathrm{CD}^{+} \mathrm{CD} 8^{+} \mathrm{T}$ cells were shown in the lungs $(\mathrm{e})$ and spleen (f) of $C_{n n n b 1^{-1-}}(n=5)$ and wild type mice $(n=5)$ infected with or without $M$. tuberculosis. The experiment had three independent rounds, and results were analyzed by the Student $t$ test. NTC, no template control. PBS, phosphate-buffered saline.

buffer. Supernatants were removed, and cells were resuspended in $100 \mu \mathrm{l}$ of Cytofix/Cytoperm (BD Pharmingen ${ }^{\mathrm{TM}}$ ), then incubated for 40 minutes at $4^{\circ} \mathrm{C}$. After washing, cells were suspended in diluted intracellular antibodies PerCP$\mathrm{Cy}^{\mathrm{TM}}$ 5.5-conjugated antihuman IFN- $\gamma$ (Clone B27, BD Phar- mingen $\left.^{\mathrm{TM}}\right)(1: 100)$ and PE/Cy7-conjugated antihuman TNF$\alpha$ (Clone MAb11, BioLegend) (1:100), incubated for 40 minutes at $4^{\circ} \mathrm{C}$, then washed with $500 \mu \mathrm{l}$ perm/wash buffer. After cell staining, cells were resuspended in $100 \mu \mathrm{l}$ of $1 \%$ paraformaldehyde. 


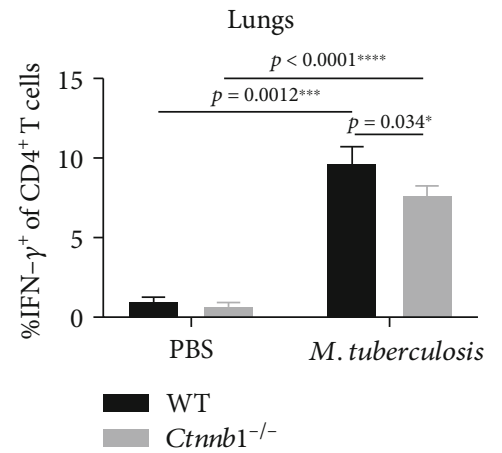

(a)

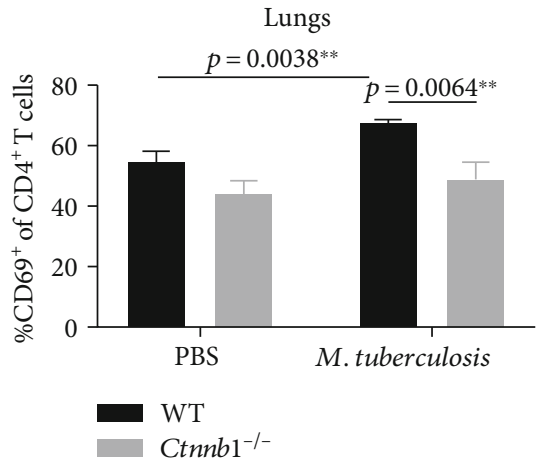

(c)

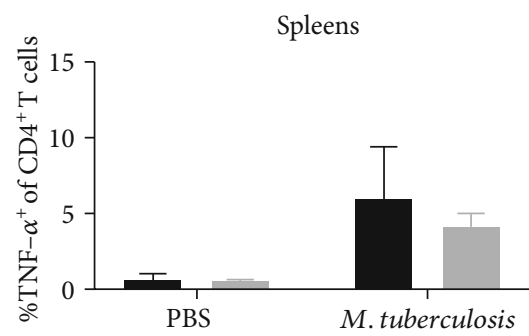

WT

$\mathrm{Ctnnb1}^{-1-}$

(e)

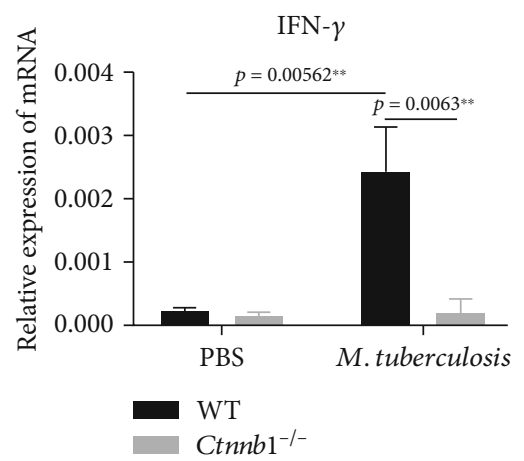

(g)

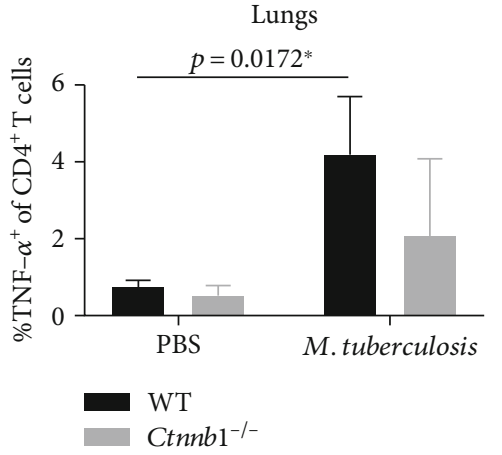

(b)

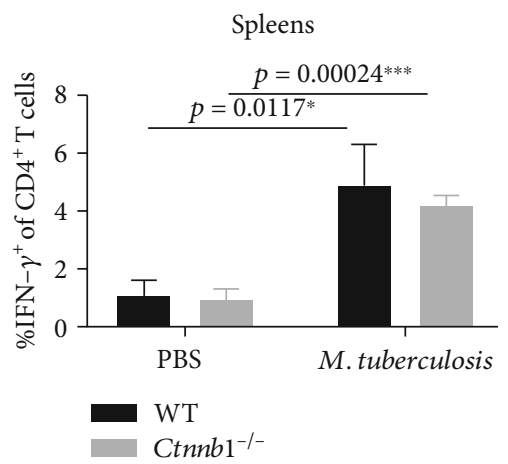

(d)

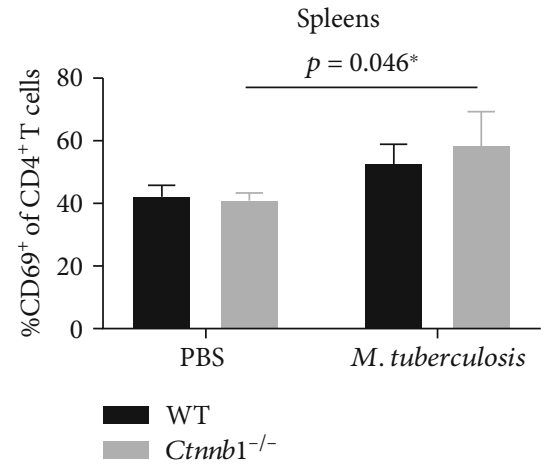

(f)

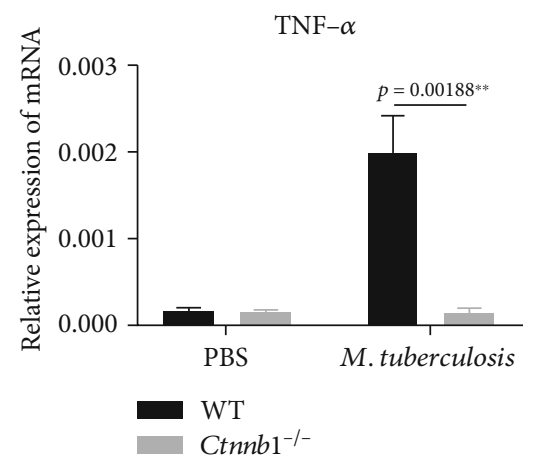

(h)

Figure 2: Continued. 


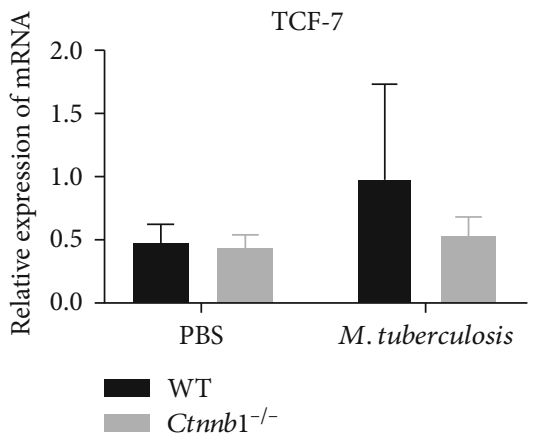

(i)

FIgure 2: The expression of IFN- $\gamma$ and TNF- $\alpha$ in $\mathrm{CD}^{+}$and $\mathrm{CD} 4^{+}$T cells. $(\mathrm{a}, \mathrm{b}) \mathrm{IFN}-\gamma^{+} \mathrm{CD} 4^{+} \mathrm{T}$ cell in the lungs and spleens of $C t n n b 1^{-/-}$mice $(n=5)$ and wild-type mice $(n=5)$ infected with or without M. tuberculosis. (c, d) TNF- $\alpha^{+} \mathrm{CD} 4^{+}$T cell in lungs and spleens of $C t n n b 1^{-1-}$ mice $(n=5)$ and wild-type mice $(n=5)$ infected with or without $M$. tuberculosis. (e, f) $\mathrm{CD}_{6} 9^{+} \mathrm{CD} 3^{+} \mathrm{CD} 4^{+} \mathrm{T}$ cells in the lungs and spleens from Ctnnb1 $1^{-1-}$ mice $(n=5)$ and wild-type mice $(n=5)$ infected with or without $M$. tuberculosis. (g, i) mRNA of IFN- $\gamma$, TNF- $\alpha$, and TCF-7 in the lungs of $C_{n n n 1^{-1-}}$ mice $(n=5)$ and wild-type mice $(n=5)$ infected with or without $M$. tuberculosis. The experiment had three independent rounds, and results were analyzed by the unpaired Student $t$-test. PBS, phosphate-buffered saline.

PBS

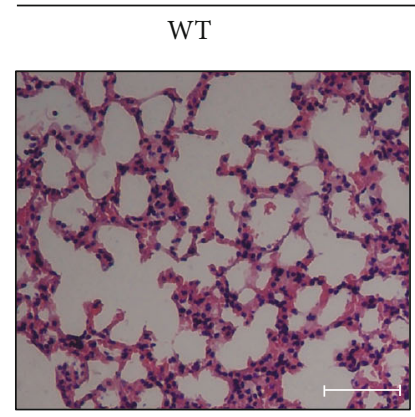

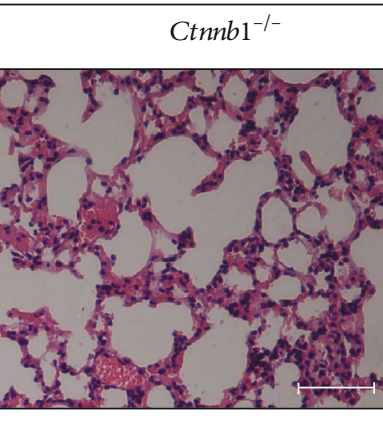

M. tuberculosis

WT Ctnnb1 ${ }^{-/-}$
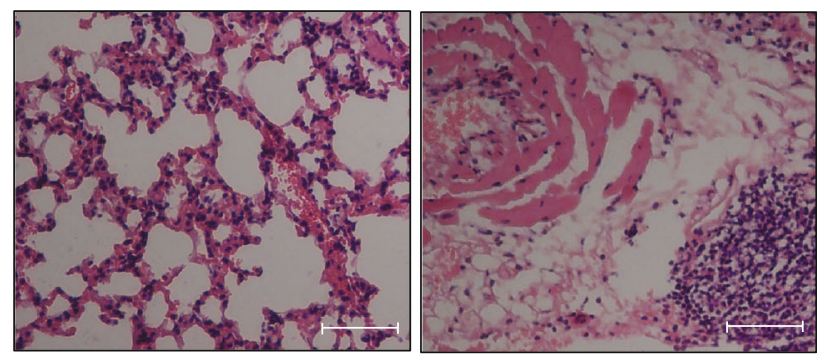

(a)

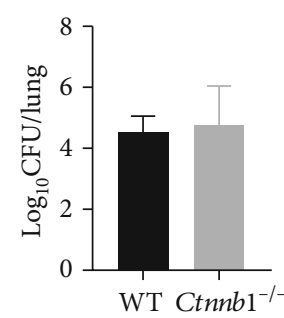

(b)

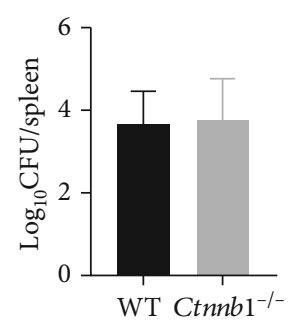

(c)

FIgURE 3: Histopathology and bacterial load of lungs (and spleens) of mice with $M t b$ infection in vivo. (a) Representative histopathology in lung sections stained with haematoxylin and eosin ( $\mathrm{H} \& \mathrm{E})$ of wild-type mice and Ctnnb1 ${ }^{-1-}$ mice infected with or without M. tuberculosis for 4 weeks (bar, $100 \mu \mathrm{m}$; original magnification $\times 200$ ). (b) Bacterial load (cfu) in the lungs of both $\mathrm{Ctnnb1}^{-1-}(n=5)$ and wild-type mice $(n=5)$ infected with M. tuberculosis for 4 weeks. (c) Bacterial load (cfu) in the spleens of both $C t n n b 1^{-1-}(n=5)$ and wild-type mice $(n=5)$ infected with $M$. tuberculosis for 4 weeks. The experiment had three independent rounds, and results were analyzed by the unpaired Student $t$-test. PBS, phosphate-buffered saline.

Data were collected using a BD Canto II flow cytometer (BD Biosciences), and at least 10,000 events were collected. The results were analyzed using FlowJo version 10.0.7 software (Tree Star, Ashland, OR, USA).

\subsection{Activation of Wnt Pathway Tested by Flow Cytometry on} PBMCs. PBMCs were incubated at $37^{\circ} \mathrm{C}$ in $5 \% \mathrm{CO}_{2}$ incubator and stimulated with $\mathrm{LiCl}$ (cat NO. L9650, Sigma) at $20 \mathrm{mM}$ for 24 hours before staining. BFA $(1 \mu \mathrm{l} / \mathrm{ml})$ was added to the cells 5 hours before staining. Then, cells were collected and stained with $\mathrm{APC} / \mathrm{H} 7$-conjugated antihuman $\mathrm{CD} 3$ (Clone SK7, BD Pharmingen $\left.^{\mathrm{TM}}\right)(1: 200), \mathrm{BB} 515$-conjugated antihuman CD4 (Clone PRA-T4, BD Horizon $\left.{ }^{\mathrm{TM}}\right)(1: 200)$, APC-conjugated antihuman CD279 (clone MIH4, BD Pharmingen $\left.^{\mathrm{TM}}\right)(1: 100)$, PerCP-Cy ${ }^{\mathrm{TM}} 5.5$-conjugated antihuman IFN- $\gamma$ (Clone B27, BD Pharmingen $\left.{ }^{\mathrm{TM}}\right)(1: 100)$, PE/Cy7- 


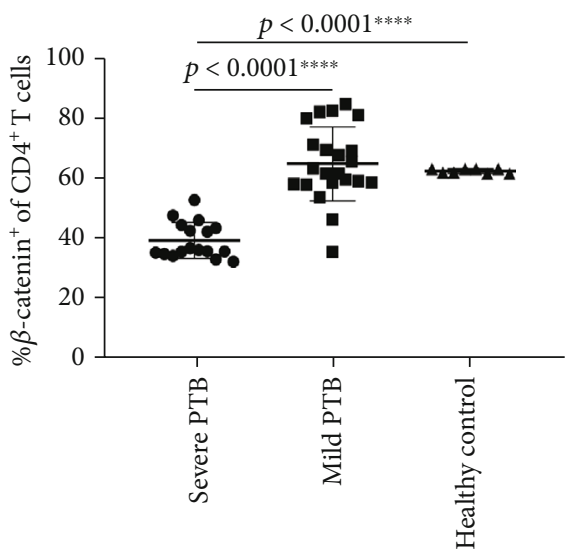

(a)

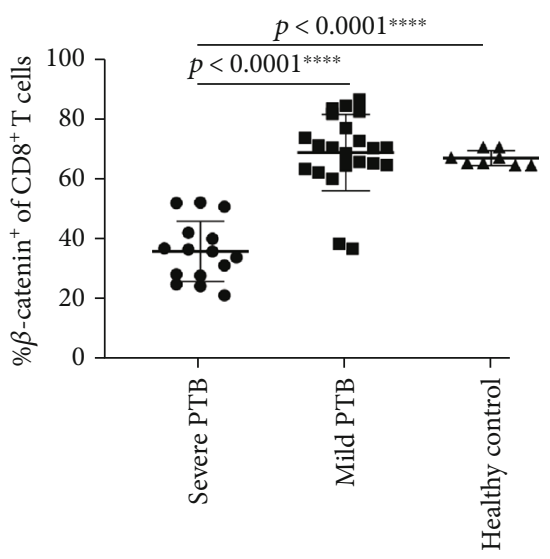

(b)

FIgure 4: Expression of $\beta$-catenin on $\mathrm{CD}^{+}$and $\mathrm{CD} 8^{+}$T cells. PBMCs from patients with severe PTB $(n=17)$, mild PTB $(n=22)$, and health controls $(n=8)$, then stained the PBMCs by flow cytometry. (a) $\beta$-catenin expression in CD4 $4^{+} \mathrm{T}$ cells. (b) $\beta$-catenin expression in CD $8^{+} \mathrm{T}$ cells. Results were analyzed by the unpaired Student $t$-test.

conjugated antihuman TNF- $\alpha$ (Clone MAb11, BioLegend) $(1: 100)$, and $\mathrm{PE}$-conjugated antihuman $\beta$-catenin (Clone $15 \mathrm{~B} 8$, eBioscience $\left.{ }^{\mathrm{TM}}\right)(1: 100)$.

2.10. Statistical Analysis. Statistical analysis was performed using the GraphPad Prism 8 software. Python 3.6 and module Seaborn Pandas were also used to analyze and plot the data. The data between the two groups were analyzed by two-tailed paired or unpaired Student $t$-test and expressed as mean \pm standard deviation, and the chi-squared test was applied to examine some of the clinical characteristic parameters. The Pearson test was performed to determine the correlation between different expression profiles on $\mathrm{CD} 4^{+}$and CD8 ${ }^{+} \mathrm{T}$ cells, $p<0.05$ for significant differences $\left({ }^{*} p<0.05\right.$; $\left.{ }^{* *} p<0.01 ;{ }^{* * *} p<0.001 ;{ }^{* * *} p<0.0001\right)$.

\section{Results}

3.1. Patient Population. Thirty-nine patients with PTB were recruited into the present study. Of them, 17 cases had severe PTB while 22 cases had mild PTB. All recruited subjects had evenly distributed ages and sexes and no severe complications with an average age of $34.8 \pm 19.2$ years old; males occupied $52.9 \%$ in severe PTB and $59.1 \%$ in mild PTB. Detailed characteristics of severe and mild lesion PTB are shown in Table 3.

3.2. Frequency of Mtb Antigen-Specific $\mathrm{CD}^{+} \mathrm{T}$ Cells Was Decreased in Infected Ctnnb1 ${ }^{-1-}$ Mice. The genotypes of all mice were identified by PCR (Figure 1(a)), and we use the genotype CD4-Cre/Ctnnb1 $1^{-1-}$ mice as $C t n n b 1^{-1-}$ mice for further research. As shown in Figure 1(b), the frequency of $\beta$ catenin $^{+}$cells in both lung and spleen $\mathrm{CD} 4^{+} \mathrm{T}$ cells was significantly decreased in $C \operatorname{Cnnb} 1^{-/-}$mice compared with that in wild-type mice ( $p=0.0038$ and 0.0107 , respectively). To confirm the changes of $\mathrm{CD}^{+} \mathrm{T}$ cells after $\mathrm{Ctnnb1^{-1- }}$ mice were infected with $M t b \mathrm{H} 37 \mathrm{Rv}$, we measured the frequency of $\mathrm{CD}^{+} \mathrm{T}$ cells in the cells from lungs and spleens of mice by flow cytometry. Results showed that after Mtb H37Rv infection, a significantly decreased frequency of $\mathrm{CD} 4^{+} \mathrm{T}$ cells in the lungs and spleens from $C t n n b 1^{-1-}$ mice was observed compared with wild-type mice ( $p=0.03$ and 0.03118 , respectively) (Figures 1(c) and 1(d)). However, the $\mathrm{CD}^{+} \mathrm{T}$ cells from the lungs and spleens were similar between $\mathrm{Ctnnb1}^{-1-}$ and wild-type mice (Figures $1(\mathrm{e})$ and $1(\mathrm{f})$ ).

3.3. Mtb Antigen-Specific Production of IFN- $\gamma$ and TNF- $\alpha$ in $\mathrm{CD}^{+} \mathrm{T}$ Cells Decreased in the Lungs of Ctnnb1 ${ }^{-1-}$ Mice. To further verify the changes of Th1 response since $\beta$-catenin in $\mathrm{CD}^{+} \mathrm{T}$ cells was knocked out in $\mathrm{Ctnn} \mathrm{1}^{-1-}$ mice, we tested IFN- $\gamma$ and TNF- $\alpha$ secreted by $\mathrm{CD} 4^{+} \mathrm{T}$ cells in both lungs and spleens. Results showed that $M t b$ antigen-specific IFN- $\gamma$ production and $\mathrm{CD} 9^{+}$expression $\mathrm{CD} 4^{+} \mathrm{T}$ cells in lungs were significantly decreased in $\mathrm{Ctnnb1}^{-1-}$ mice compared with wild-type mice $(p=0.034$ and 0.0064 , respectively) (Figures $2(\mathrm{a})$ and $2(\mathrm{c})$ ), indicating $\beta$-catenin is able to promote the Th1 cytokine production and activate $\mathrm{CD} 4^{+} \mathrm{T}$ cells, although the difference in frequency of TNF- $\alpha^{+} \mathrm{CD}^{+} \mathrm{CD}^{+} \mathrm{T}$ cells had no statistical significance between the two groups in the lungs (Figure 2(b)). Meanwhile, Mtb antigen-specific IFN- $\gamma$ and TNF- $\alpha$ production by $\mathrm{CD}^{+} \mathrm{T}$ cells and the frequency of $\mathrm{CD} 69^{+} \mathrm{CD} 4^{+} \mathrm{T}$ cells in the spleens was kept similar between the infected $C t n n b 1^{-/-}$and wild-type mice (Figures 2(d)-2(f)). IFN- $\gamma$ and TNF- $\alpha$ mRNA in the lungs of infected $\mathrm{Ctnnb1}^{-1-}$ mice were significantly decreased compared with those in infected wild-type mice ( $p=0.0063$ and 0.00188 , respectively), while no difference was found in TCF-7 mRNA between two groups of mice (Figures 2(g)-2(i)).

In addition, the expression of IFN- $\gamma$, TNF- $\alpha$, CD69, and IFN- $\gamma$ mRNA in the lung $\mathrm{CD}^{+} \mathrm{T}$ cells and IFN- $\gamma$ in spleen $\mathrm{CD} 4^{+} \mathrm{T}$ cells significantly elevated after infection in WT mice $(p=0.00012,0.0172,0.0038,0.00562$, and 0.0117 , respectively) (Figure 2).

3.4. The Lungs of $\mathrm{Ctnnb1}^{-1-}$ Mice Exhibited Slightly More Pathological Inflammation and Similar Bacterial Load Compared with Wild-Type Mice. The lung tissue was 


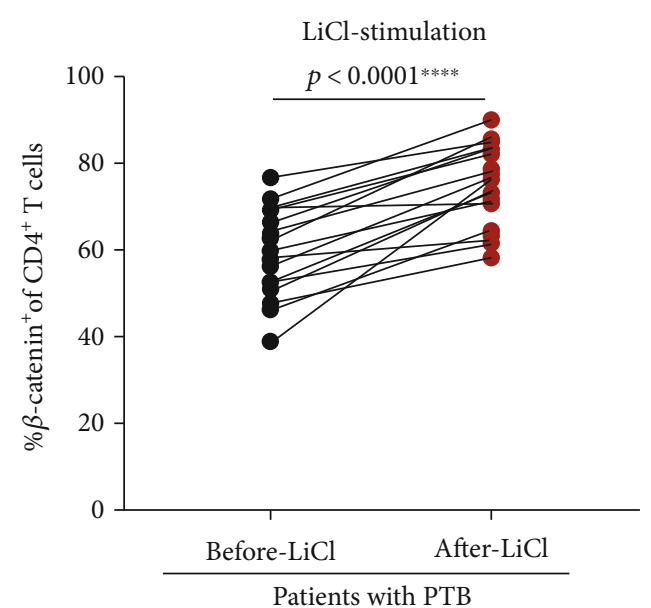

(a)

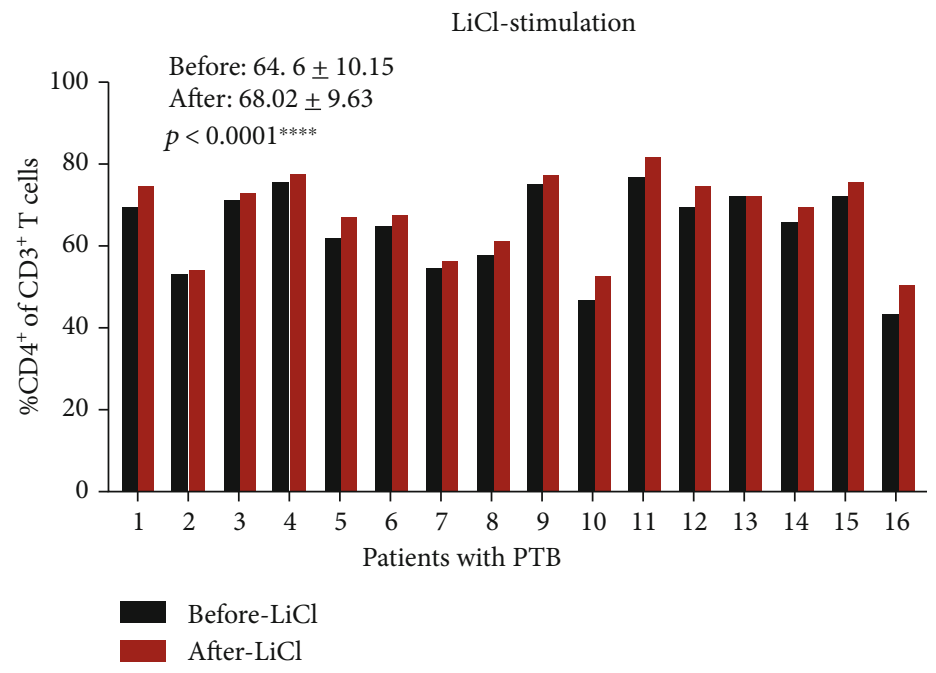

(b)

LiCl-stimulation

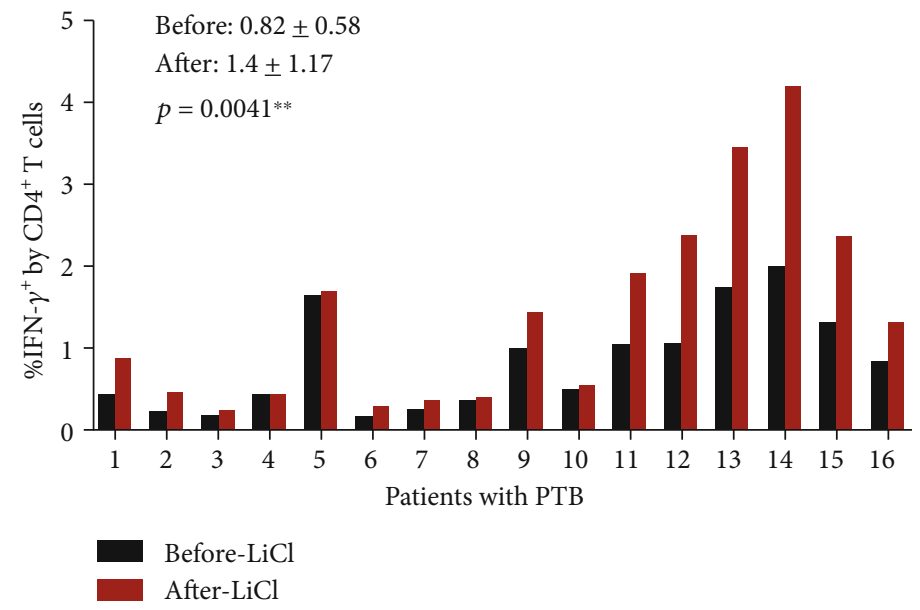

(c)

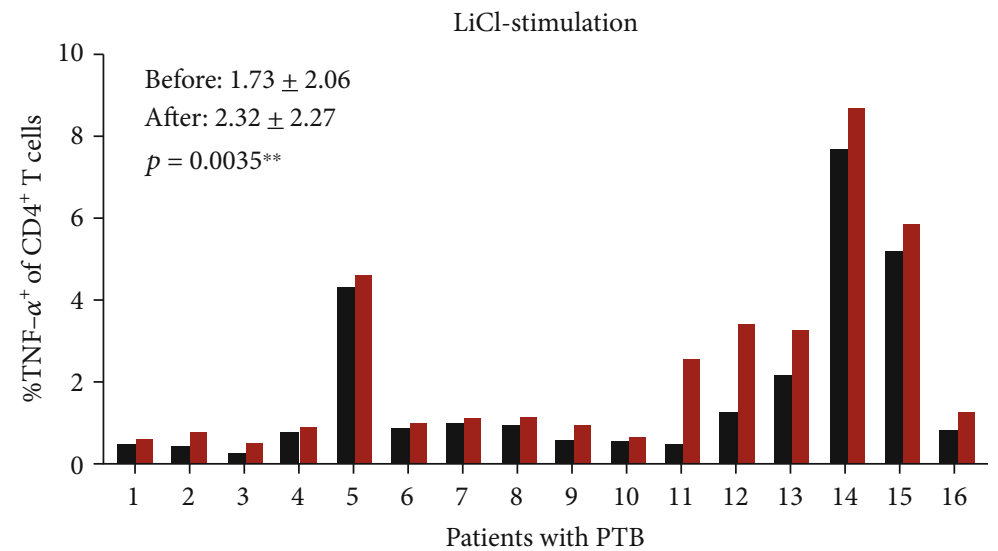

Before-LiCl

After-LiCl

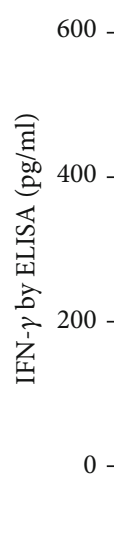

LiCl-stimulation

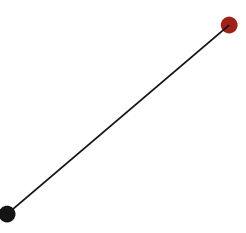

Before-LiCl After-LiCl

Patients with PTB

(d)

(e)

Figure 5: Continued. 


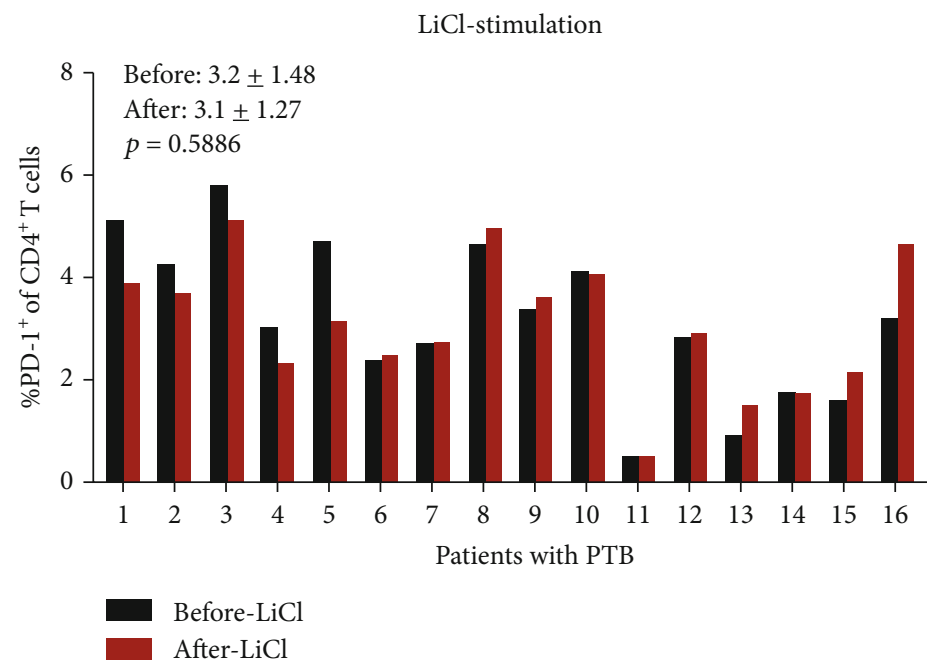

(f)

FIgURe 5: PBMCs cultured with $\mathrm{LiCl}$ to stimulate the production of $\beta$-catenin. (a) Significant increase in the $\beta$-catenin expression on $\mathrm{CD} 4^{+} \mathrm{T}$ cells after LiCl stimulation, $n=16$. (b) Significant increase in the $\mathrm{CD}^{+}$frequency after $\mathrm{LiCl}$ stimulation, $n=16$. (c) Significant increase in the IFN- $\gamma$ expression on $\mathrm{CD}^{+} \mathrm{T}$ cells after $\mathrm{LiCl}$ stimulation, $n=16$. (d) Significant increase in the TNF- $\alpha$ expression on CD $4^{+} \mathrm{T}$ cells after LiCl stimulation, $n=16$. (e) The ELISA result showed similar IFN- $\gamma$ expression before after LiCl stimulation, $n=10$. (f) No changes of PD-1 expression on $\mathrm{CD}^{+} \mathrm{T}$ cells after $\mathrm{LiCl}$ stimulation, $n=16$. All results were analyzed by the paired Student $t$-test.

collected, with the pathological changes observed in infected $C \operatorname{Cnnb1^{-1-}}$ mice. We found that the lungs in $C \operatorname{tnnb1^{-1-}}$ mice exhibited more profound inflammatory changes compared with those in wild-type mice infected (Figure 3(a)). However, we found no differences in bacterial load in lungs and spleens between $\mathrm{Ctnnb1}^{-1-}$ and wild-type mice ( $p=0.7098$ and 0.899 , respectively) (Figures $3(\mathrm{~b})$ and $3(\mathrm{c})$ ).

3.5. Expression of $\beta$-Catenin in $C D 4^{+} T$ Cells Was Decreased in PBMCs of Patients with Severe PTB. To determine the expression characteristics of $\beta$-catenin in T cells of PTB patients, we tested the $\beta$-catenin in PBMCs of PTB patients by flow cytometry. As the nuclear molecules can be stained with flow cytometry antibodies by using Transcription Factor Buffer Set (BD Pharmingen ${ }^{\mathrm{TM}}$ ), we could observe a very high frequency of $\beta$-catenin ${ }^{+}$cells in most samples. The results showed that $\beta$-catenin in $\mathrm{CD} 4^{+} \mathrm{T}$ cells was decreased significantly in patients with severe PTB than that in patients with mild PTB $(p<0.0001), \beta$-catenin in $\mathrm{CD}^{+}{ }^{+} \mathrm{T}$ cells of patients with severe PTB was accordingly significantly lower than that in healthy donors $(p<0.0001)$, while $\beta$-catenin expression was similar between patients with mild PTB and healthy donors $(p=0.5771)$ (Figure $4(\mathrm{a}))$.

3.6. Expression of $\beta$-Catenin in $C D 8^{+} T$ Cells in PBMCs of Patients with Severe PTB and Its Lower Frequency Compared with That in Patients with Mild PTB. To compare the expression of $\beta$-catenin in $\mathrm{CD}^{+} \mathrm{T}$ cells of PTB patients, we tested $\beta$-catenin expression in $\mathrm{CD}^{+} \mathrm{T}$ cells of $\mathrm{PTB}$ patients by flow cytometry. The results showed that $\beta$ catenin in $\mathrm{CD}^{+} \mathrm{T}$ cells was decreased significantly in patients with severe PTB than that in patients with mild PTB and healthy donors as well ( $p<0.0001$, both), while $\beta$ - catenin expression was similar in between patients with mild PTB and healthy donors $(p=0.6897)$ (Figure $4(b))$.

\section{7. $\beta$-Catenin Can Promote Th1 Cytokine Secretion and} Increase the Frequency of $\mathrm{CD}^{+} \mathrm{T}$ Cells, rather than the $\mathrm{PD}$ 1 Expression, in Patients with PTB. $\mathrm{LiCl}$, a stimulant of $\beta$ catenin, was added into the cultures of PBMCs to increase the $\beta$-catenin expression. The results showed that the percentage of $\beta$-catenin expressing in $\mathrm{CD}^{+} \mathrm{T}$ cells was increased significantly $(p<0.0001)$, and $\mathrm{CD} 4^{+} \mathrm{T}$ cells were also significantly increased under stimulation of $\mathrm{LiCl}$ $(p<0.0001)$. Meanwhile, Th1 cytokines produced by $\mathrm{CD} 4^{+}$ T cells, including IFN- $\gamma$ and TNF- $\alpha$, were significantly increased after the simulation of $\mathrm{LiCl}(p=0.0041$ and 0.0035 , respectively) (Figures 5(a)-5(d)), while the result of ELISA showed similar IFN- $\gamma$ secretion in PTB patients before and after stimulation of $\mathrm{LiCl}$ (before - $\mathrm{LiCl}$ group vs. after $-\mathrm{LiCl}$ group $=82.88 \pm 151.17$ vs. $45.25 \pm 74.98, p=$ 0.177 ) (Figure 5(e)). In addition, PD- 1 expression in $\mathrm{CD} 4^{+}$ $\mathrm{T}$ cells was not obviously increased or decreased under the stimulation of $\mathrm{LiCl}(p=0.5886)$ (Figure 5(f)).

3.8. $\beta$-Catenin Showed a Weak Positive Correlation with PD1 Expression and Had No Correlation with IFN- $\gamma$ on Both $\mathrm{CD}^{+}$and $\mathrm{CD}^{+} \mathrm{T}$ Cells. We tested the expression of $\beta$ catenin, IFN- $\gamma$, and PD-1 in CD4 ${ }^{+} \mathrm{T}$ cells from PBMCs of the same group of PTB patients through flow cytometry. The data showed that $\beta$-catenin had moderately positive correlation with PD-1 $\left(R^{2}=0.39 ; p=0.03\right)\left(R^{2}\right.$ : Pearson $r$ score $)$ (Figures 6(a) and 6(b)). We also tested the expression of $\beta$ catenin, IFN- $\gamma$, and PD- 1 in $\mathrm{CD}^{+} \mathrm{T}$ cells from PBMCs of the same group of PTB patients through flow cytometry. The data showed that the production of $\beta$-catenin and PD- 1 were also positively moderately correlated $\left(R^{2}=0.39 ; p=0.0096\right)$, 

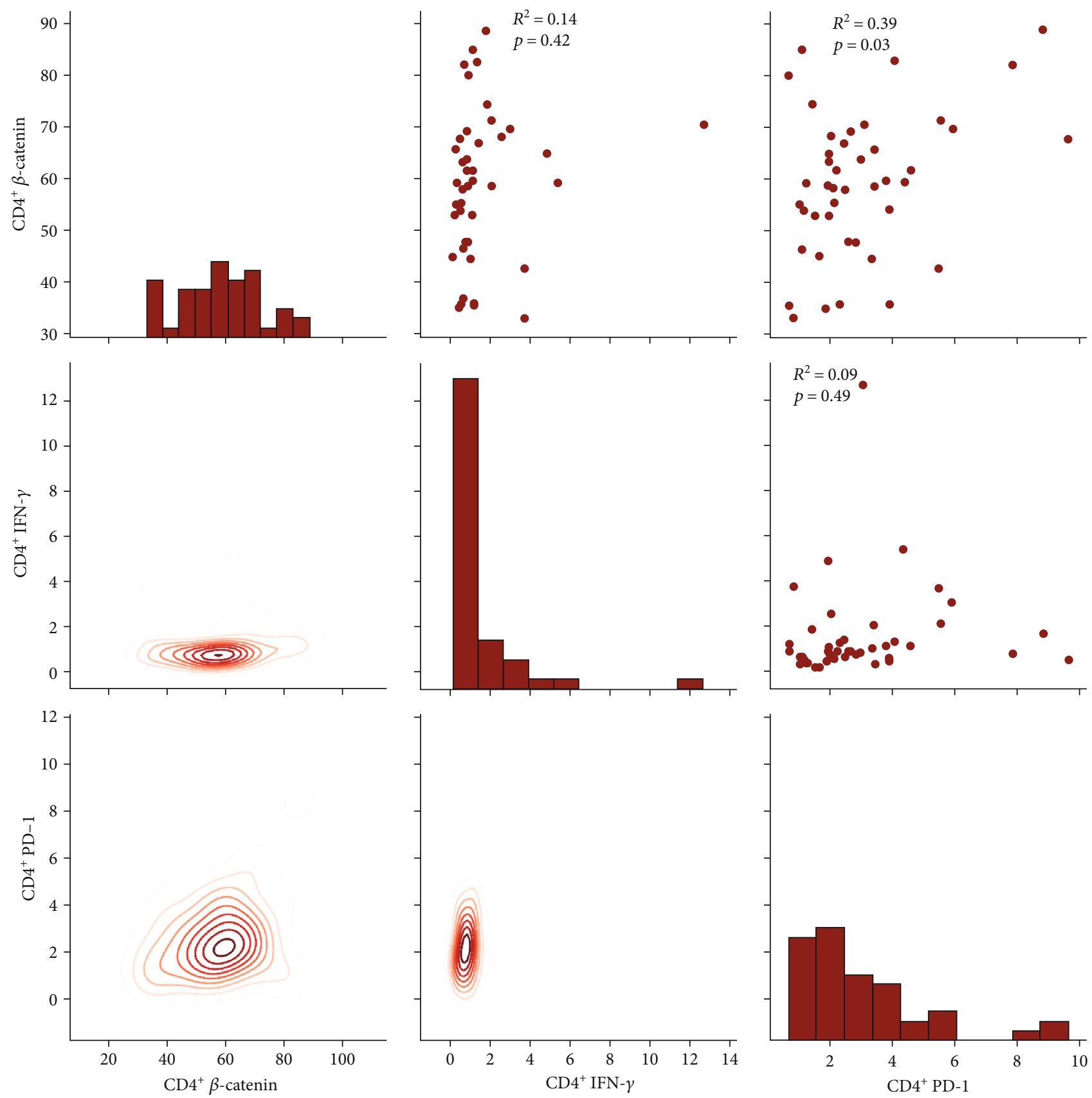

(a)

FIgUre 6: Continued. 


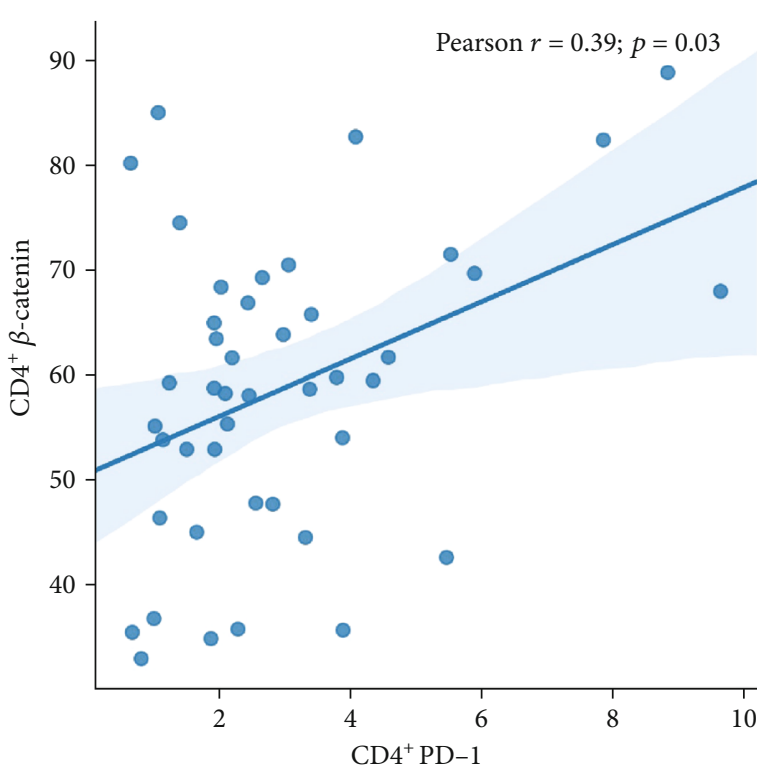

(b)

Figure 6: (a) The correlation of $\beta$-catenin, PD-1, and IFN- $\gamma$ on CD4 T cells. (b) The correlation of $\beta$-catenin and PD- 1 on CD4 T cells $(n=47)$.

and the correlation of $\mathrm{CD} 8^{+} \mathrm{PD}-1^{+}$and $\mathrm{CD} 8^{+} \mathrm{IFN}-\gamma^{+}$cells was weak to moderate $\left(R^{2}=0.28 ; p=0.04\right)$ (Figures $7(\mathrm{a})$ and $\left.7(\mathrm{~b})\right)$. The molecular mechanisms underlying the positive correlation between $\beta$-catenin and PD- 1 remain to be determined.

3.9. $\beta$-Catenin, PD-1, and IFN- $\gamma$ in $C D 4^{+} T$ Cells Are Highly Correlated with Their Respective Expression in $C D 8^{+} \mathrm{T}$ Cells. After the analysis of the expression level of $\beta$-catenin and IFN- $\gamma$ in $\mathrm{CD}^{+}$and $\mathrm{CD}^{+}$T cells, we found $\beta$-catenin in $\mathrm{CD}^{+} \mathrm{T}$ cells was highly correlated with that in $\mathrm{CD}^{+} \mathrm{T}$ cells, with $R^{2}$ equal to $0.94(p=7 \mathrm{e}-21)$. IFN- $\gamma$ in $\mathrm{CD}^{+}$cell was also highly associated with its expression in $\mathrm{CD}^{+} \mathrm{T}$ cell, with $R^{2}$ equal to $0.94(p=6.7 \mathrm{e}-21)$, PD- 1 in $\mathrm{CD} 4^{+} \mathrm{T}$ cells moderately associated with its expression in $\mathrm{CD}^{+} \mathrm{T}$ cells, and $R^{2}$ was $0.47(p=0.0014)$. The data are shown in Figures $8(a)-8(c)$.

\section{Discussion}

$\beta$-Catenin has been thought to be involved in the regulation of cell fate, such as proliferation, differentiation, and apoptosis or T cell development $[16,17]$. In most published studies, $\beta$-catenin has a close association with the pathogenesis of malignant diseases and is a therapeutic target for cancer in view of its function to promote tumor cell proliferation [18]. $\beta$-Catenin is a core molecule in the canonical Wnt/ $\beta$ catenin pathway, through the ubiquitin-proteasome system (UPS); it is kept at a low level in the absence of Wnt ligands. Upon Wnt activation, $\beta$-catenin accumulates in the cytoplasm, then enters into the nucleus and binds to some coregulators to promote the transcription of some genes, such as $C y c l i n D(c y c D), c-m y c$, and $c$-Jun, which, in turn, regulate the cell fate. Thus, the protein level of $\beta$-catenin in the whole cell can be associated with the activation of the canonical $\mathrm{Wnt} / \beta$-catenin pathway. Our previous study showed that $\beta$-catenin mRNA in CD14- cells was impaired in severe
PTB patients, and stimulation of $\beta$-catenin could enhance the activation of $\mathrm{CD}^{+}{ }^{+} \mathrm{T}$ cells in the blood of PTB [15]. In the present study, the frequency of $\mathrm{CD}^{+} \mathrm{T}$ cells in conditional $\mathrm{Ctnnb1}^{-/-}$infected mice was decreased, indicating a role of $\beta$-catenin in the activation and proliferation of $\mathrm{CD} 4^{+} \mathrm{T}$ cells of hosts infected with TB.

Results from Kared et al. [19] indicate that the Wnt/ $\beta$ catenin axis may represent a key pathway in reversing $\mathrm{T}$ cell defects and was associated with the heterogeneity of CD $4^{+} \mathrm{T}$ cells in humans. Our studies also showed that Th1 response was impaired in $C t n n b 1^{-/-}$infected mice, implying that the $\mathrm{Wnt} / \beta$-catenin pathway might play a role in the process of regulating $\mathrm{CD}^{+} \mathrm{T}$ cell activation, differentiation, and $\mathrm{Th} 1$ response in host with TB. Meanwhile, the study showed the slightly more obvious inflammation cells gathering in $\mathrm{Ctnnb1}^{-/-}$mice compared to wild-type mice, while both groups demonstrated similar bacteria loads in both lungs and spleens, implying that $\beta$-catenin might participate in the regulation of functional effects of Th1 and proliferation of $\mathrm{CD}^{+} \mathrm{T}$ cells, leading to immunological damage. We did not find the change in bacterial load in $\mathrm{Ctnnb1}^{-1-}$ mice, which was possibly stemmed from multiple other factors involved in the bacteria growth.

To further confirm the conclusions in mice experiments, we recruited a group of PTB patients, who were divided into mild and severe groups. Then, we obtained blood samples, isolated PBMCs, and tested $\beta$-catenin expression in $\mathrm{CD} 4^{+}$ and $\mathrm{CD} 8^{+} \mathrm{T}$ cells by flow cytometry. We also stained the cells with anti-IFN- $\gamma$, TNF- $\alpha$, and PD- 1 antibodies. We found that $\beta$-catenin expression in both $\mathrm{CD}^{+}$and $\mathrm{CD}^{+} \mathrm{T}$ cells was significantly impaired in severe compared to mild subjects. Unlike our previous study, the $\beta$-catenin expression also underwent remarkable changes in $\mathrm{CD}^{+} \mathrm{T}$ cells in PTB patients in a similar way as in $\mathrm{CD} 4^{+} \mathrm{T}$ cells. $\beta$-Catenin had been studied in the ovarian tumors, and results showed that 

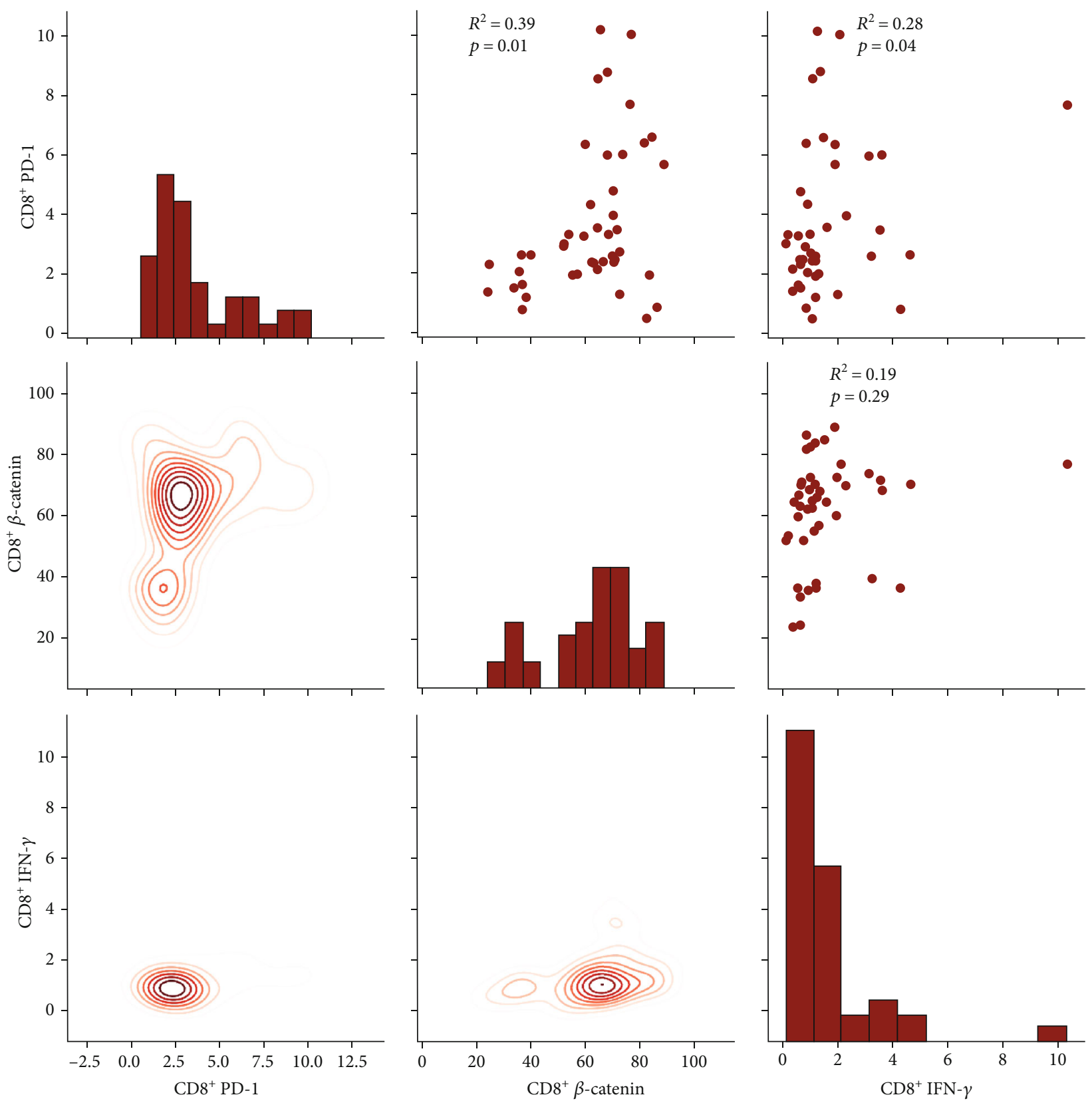

(a)

Figure 7: Continued. 


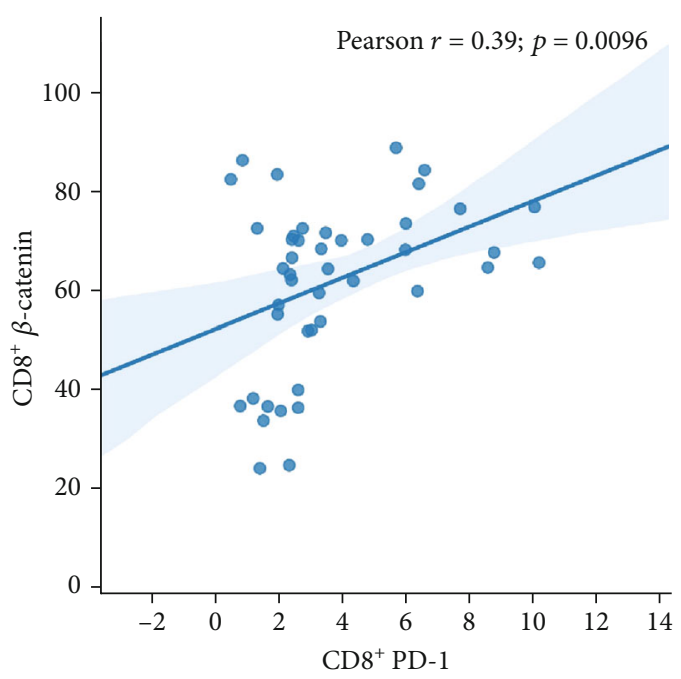

(b)

FIgURE 7: (a) The correlation of $\beta$-catenin, PD-1, and IFN- $\gamma$ on CD8 T cells. (b) The correlation of $\beta$-catenin and PD- 1 on CD8 T cells ( $n=47)$.

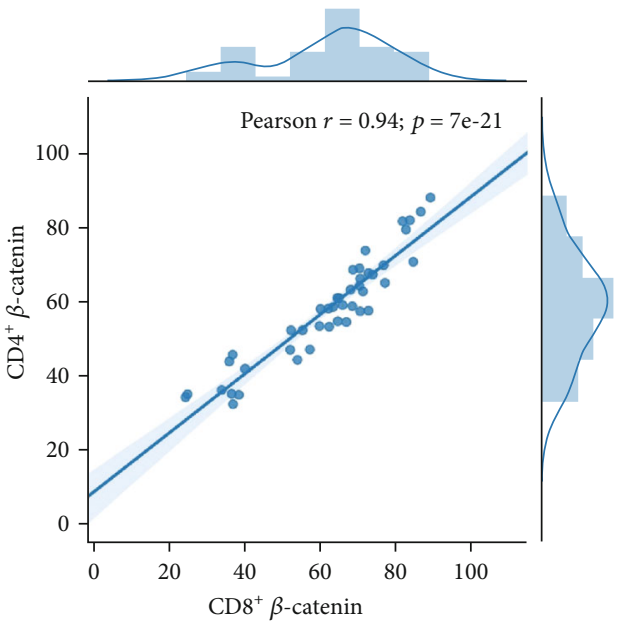

(a)

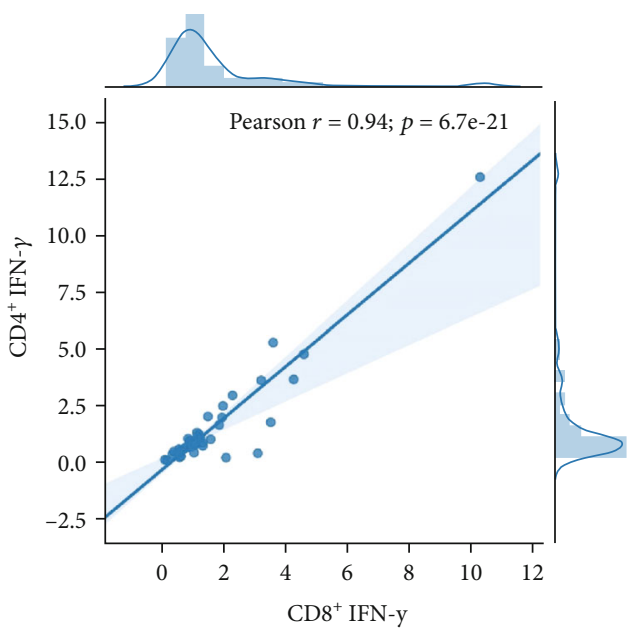

(b)

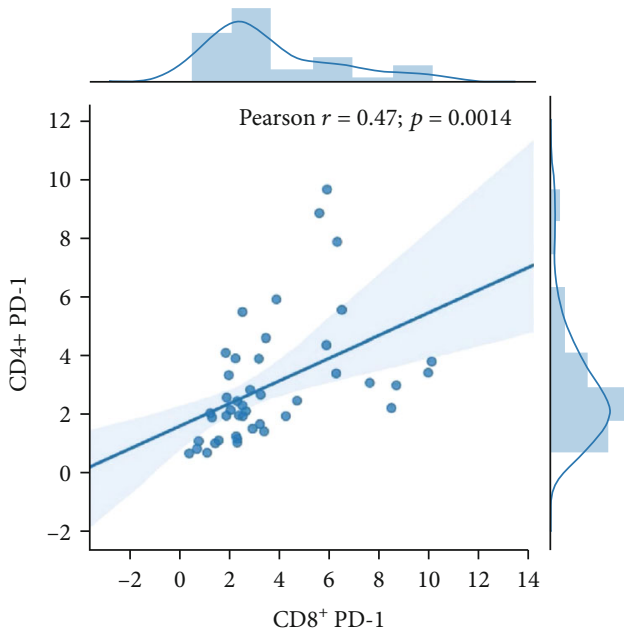

(c)

FIGURE 8: (a) The correlation of $\beta$-catenin on CD4 T cells and $\beta$-catenin on CD8 T cells. (b) The correlation of IFN- $\gamma$ on CD4 T cells and IFN$\gamma$ on CD8 T cells. (c) The correlation of PD-1 on CD4 T cells and PD-1 on CD8 T cells $(n=47)$. 
the blocking Wnt/ $\beta$-catenin pathway in $\mathrm{CD}^{+} \mathrm{T}$ cells at least partly explains the retardation of tumor growth and improvement of patient survival [20]. In T cell inflammation of tumor microenvironment, such as in colorectal cancer, $\mathrm{Wnt} / \beta$-catenin pathway plays an essential role in $\mathrm{CD}^{+} \mathrm{T}$ cells activation [21], since intrinsic $\beta$-catenin can suppress the $\mathrm{CD}^{+} \mathrm{T}$ cells infiltration, resulting in the mediation of colorectal cancer resistance to chemotherapy [22]. The present TB study showed that $\beta$-catenin in both $\mathrm{CD} 4^{+}$and $\mathrm{CD} 8^{+}$ T cells had a close association with the regulation of TB progress. Increased $\beta$-catenin can enhance the expression of Th1 responses in the $\mathrm{CD} 4^{+} \mathrm{T}$ population, which is consistent with our previous study [15]. Interestingly, the frequency of IFN- $\gamma$ in $\mathrm{CD} 4^{+} \mathrm{T}$ cells was significantly increased in PBMCs of PTB patients after $\mathrm{LiCl}$ stimulation compared with before $\mathrm{LiCl}$ stimulation (Figure 5(c)), while IFN- $\gamma$ measurements by ELISA of PTB patients' PBMCs did not show differences between before and after $\mathrm{LiCl}$ stimulation (Figure 5(e)), indicating that increased $\beta$-catenin did not enhance the whole IFN- $\gamma$ secretion but IFN- $\gamma$ secretion from some kinds of cells such as $\mathrm{CD} 4^{+} \mathrm{T}$ cells in the PBMCs of PTB patients.

As $\beta$-catenin was impaired in severe $\mathrm{PTB}$, in whom the frequency of $\mathrm{CD}^{+} \mathrm{T}$ cells decreased [14], we wondered whether decreased $\mathrm{CD} 4^{+} \mathrm{T}$ cells and Th1 secretion was associated with changed PD-1 expression or impaired Th1 expression was due to PD-1 involvement. The results indicated that the variation in $\beta$-catenin could stimulate the $\mathrm{CD}^{+} \mathrm{T}$ cells and Th1 cytokines expression, though PD-1 expression on $\mathrm{CD}^{+}{ }^{+} \mathrm{T}$ cells was not influenced. But the level of $\beta$-catenin showed a moderate positive correlation with PD-1 rather than Th1 cytokine production, implying the role of $\beta$-catenin had partly associated with PD- 1 but had no direct or crucial association. In view of the role of $\beta$-catenin showed in a tumor study, in which $\beta$-catenin promote immune escape and impair $\mathrm{T}$ cells activity, resulting in resistance to anti-PD-1 therapy in hepatocellular carcinoma [23], $\beta$-catenin has been applied in the anticancer strategy of therapy in combination with PD-1 immunotherapy [24]. PD-1 has been thought to be an exhaustion marker on $\mathrm{T}$ cell surface $[25,26]$, suggesting decreased $\mathrm{CD}^{+} \mathrm{T}$ cells in severe PTB are associated with impaired $\beta$-catenin and $\mathrm{T}$ cell exhaustion.

The other interesting finding in the present study was that $\beta$-catenin, PD- 1 , and IFN- $\gamma$ in $\mathrm{CD} 4^{+} \mathrm{T}$ cells had strong correlations with their respective expression in $\mathrm{CD}^{+} \mathrm{T}$ cells. In our earlier research, we observed a variation in the number of $\mathrm{CD}^{+} \mathrm{T}$ cells and their cytokine production, but not in $\mathrm{CD}^{+} \mathrm{T}$ cells between severe and mild PTB subjects, but we confirmed the decrease in the number of $\mathrm{CD} 4^{+} \mathrm{T}$ cells and impaired Th1 cytokine production in Ctnnb1 conditional knocked mice as expected. However, in human studies, a similar changing trend of $\mathrm{CD}^{+} \mathrm{T}$ cells was found, indicating that $\beta$-catenin could participate in the regulation of cell proliferation and activation of both $\mathrm{CD} 4^{+}$and $\mathrm{CD} 8^{+} \mathrm{T}$ cells. In conclusion, $\beta$-catenin can promote $\mathrm{CD} 4^{+}$and $\mathrm{CD}^{+} \mathrm{T}$ cell activation and play a role in immune protection in $\mathrm{TB}$ infection.

In summary, this study focused on the role and expression of $\beta$-catenin in $\mathrm{TB}$ in both mouse experiments and human studies. The results showed $\beta$-catenin elevated $\mathrm{T}$ cell number and Th1 cytokine secretion by $\mathrm{CD}^{+} \mathrm{T}$ cells. $\beta$ Catenin may be involved in the pathogenesis of TB diseases by impairing $\mathrm{CD}^{+}$and $\mathrm{CD}^{+} \mathrm{T}$ cells, which is, at least, attributing to $\mathrm{PD}-1$-induced exhaustion.

\section{Data Availability}

The data used to support the findings of this study are available from the corresponding author upon request.

\section{Ethical Approval}

This prospective study was approved by the Ethics Committee of the Shanghai Pulmonary Hospital (approval number: fk17-022).

\section{Consent}

Each participant or their legal representatives gave written informed consent before enrollment.

\section{Disclosure}

The funders had no role in study design, data collection and analysis, decision to publish, or preparation of the manuscript.

\section{Conflicts of Interest}

The authors have declared that no competing interests exist.

\section{Authors' Contributions}

$\mathrm{LF}$ and $\mathrm{CZ}$ were responsible for the conception and design of the study. LF and KX were responsible for the acquisition and analysis of data; furthermore, LF was in charge of writing and revising the manuscript and statistical analysis, KX, LW, JN, and YS operated the experiment. All authors read and approved the final submitted version.

\section{Acknowledgments}

We thank all participants for their time and efforts. This work was supported by the 13th Five-Year National Science and Technology Major Project for Infectious Diseases, China (Grant No.2018ZX10725-509) and the natural science fund from Shanghai Committee of Science and Technology, China (Grant No. 20ZR1446700).

\section{References}

[1] T. Villaseñor, E. Madrid-Paulino, R. Maldonado-Bravo, A. Urbán-Aragón, L. Pérez-Martínez, and G. Pedraza-Alva, "Activation of the Wnt pathway by Mycobacterium tuberculosis: a Wnt-Wnt situation," Frontiers in Immunology, vol. 8, p. 50, 2017.

[2] C. S. L. Arlehamn, D. Lewinsohn, A. Sette, and D. Lewinsohn, "Antigens for CD4 and CD8 T cells in tuberculosis," Cold Spring Harbor Perspectives in Medicine, vol. 4, no. 7, article a18465, 2014 
[3] Q. Yu, A. Sharma, and J. M. Sen, "TCF1 and beta-catenin regulate $\mathrm{T}$ cell development and function," Immunologic Research, vol. 47, no. 1-3, pp. 45-55, 2010.

[4] Z. Huang, H. Xie, V. Ioannidis et al., "Transcriptional regulation of CD4 gene expression by $\mathrm{T}$ cell factor-1/beta-catenin pathway," The Journal of Immunology, vol. 176, no. 8, pp. 4880-4887, 2006.

[5] K. Hoffmeyer, A. Raggioli, S. Rudloff et al., "Wnt/-catenin signaling regulates telomerase in stem cells and cancer cells," Science, vol. 336, no. 6088, pp. 1549-1554, 2012.

[6] X.-F. Jin, G. Spöttl, J. Maurer, S. Nölting, and C. J. Auernhammer, "Inhibition of $\mathrm{Wnt} / \beta$-catenin signaling in neuroendocrine tumors in vitro: antitumoral effects," Cancers, vol. 12, no. 2, p. 345, 2020.

[7] X. Zhao, D. Li, F. Yang et al., "Long noncoding RNA NHEG1 Drives $\beta$-catenin transactivation and neuroblastoma progression through interacting with DDX5," MOL THER, vol. 28, no. 3, pp. 946-962, 2020.

[8] N. Taye, A. Alam, S. Ghorai et al., "SMAR1 inhibits Wnt/ $\beta$ catenin signaling and prevents colorectal cancer progression," Oncotarget, vol. 9, no. 30, pp. 21322-21336, 2018.

[9] O. Silva-García, J. J. Valdez-Alarcón, and V. M. BaizabalAguirre, "Wnt/ $\beta$-catenin signaling as a molecular target by pathogenic bacteria," FRONT IMMUNOL, vol. 10, p. 2135, 2019.

[10] X. Wu, G. Deng, M. Li et al., "Wnt/ $\beta$-catenin signaling reduces Bacillus Calmette-Guerin-induced macrophage necrosis through a ROS-mediated PARP/AIF-dependent pathway," BMC Immunology, vol. 16, no. 1, 2015.

[11] X. Wu, J. Zhang, C. Ma et al., "A role for Wnt/ $\beta$-catenin signalling in suppressing Bacillus Calmette-Guerin-induced macrophage autophagy," Microbial Pathogenesis, vol. 127, pp. 277287, 2019.

[12] X. Wu, G. Deng, X. Hao et al., “A caspase-dependent pathway is involved in $\mathrm{Wnt} / \beta$-catenin signaling promoted apoptosis in Bacillus Calmette-Guerin infected RAW264.7 macrophages," International Journal of Molecular Sciences, vol. 15, no. 3, pp. 5045-5062, 2014.

[13] W. J. Zhou, X. J. Hu, J. Y. Zhang et al., “Association of gene polymorphisms in Wnt signal pathway with tuberculosis in Chinese Tibetan population," Sichuan Da Xue Xue Bao Yi Xue Ban, vol. 47, p. 920, 2016.

[14] L. Fan, H. Xiao, G. Mai, B. Su, J. Ernst, and Z. Hu, "Impaired M. tuberculosis antigen-specific IFN- $\gamma$ response without IL17 enhancement in patients with severe cavitary pulmonary tuberculosis," Plos One, vol. 10, no. 5, article e127087, 2015.

[15] L. Fan, H. Shen, H. Huang, R. Yang, and L. Yao, "Impairment of $\mathrm{Wnt} / \beta$-catenin signaling in blood cells of patients with severe cavitary pulmonary tuberculosis," Plos One, vol. 12, no. 3, article e172549, p. e0172549, 2017.

[16] C. J. Aros, M. K. Paul, C. J. Pantoja et al., "High-throughput drug screening identifies a potent Wnt inhibitor that promotes airway basal stem cell homeostasis," Cell Reports, vol. 30, no. 7, pp. 2055-2064.e5, 2020.

[17] A. Bigas, Y. Guillén, L. Schoch, and D. Arambilet, "Revisiting $\beta$-catenin signaling in T-cell development and T-cell acute lymphoblastic leukemia," BioEssays, vol. 42, no. 2, article 1900099, 2020.

[18] M. O. F. Sikder, S. Sivaprakasam, T. P. Brown, M. Thangaraju, Y. D. Bhutia, and V. Ganapathy, "SLC6A14, a Na+/Cl-coupled amino acid transporter, functions as a tumor promoter in colon and is a target for Wnt signaling," Biochemical Journal, vol. 477, no. 8, pp. 1409-1425, 2020.

[19] H. Kared, S. W. Tan, M. C. Lau et al., "Immunological history governs human stem cell memory CD4 heterogeneity via the Wnt signaling pathway," Nature Communications, vol. 11, no. 1, p. $821,2020$.

[20] W. N. Goldsberry, S. Meza-Perez, A. I. Londoño et al., "Inhibiting WNT ligand production for improved immune recognition in the ovarian tumor microenvironment," Cancers, vol. 12, no. 3, p. 766, 2020.

[21] X. Li, Y. Xiang, F. Li, C. Yin, B. Li, and X. Ke, "WNT/ $\beta$-catenin signaling pathway regulating T cell-inflammation in the tumor microenvironment," Frontiers in Immunology, vol. 10, p. 2293, 2019.

[22] J. Xue, X. Yu, L. Xue, X. Ge, W. Zhao, and W. Peng, "Intrinsic $\beta$-catenin signaling suppresses $\mathrm{CD}^{+} \mathrm{T}$-cell infiltration in colorectal cancer," Biomedicine \& Pharmacotherapy, vol. 115, article 108921, 2019.

[23] M. R. de Galarreta, E. Bresnahan, P. Molina-Sánchez et al., “ $\beta$ catenin activation promotes immune escape and resistance to anti-PD-1 therapy in hepatocellular carcinoma," Cancer Discovery, vol. 9, no. 8, pp. 1124-1141, 2019.

[24] M. Feng, J. Q. Jin, L. Xia et al., "Pharmacological inhibition of $\beta$-catenin/BCL9 interaction overcomes resistance to immune checkpoint blockades by modulating T(reg) cells," Science Advances, vol. 5, article eaau5240, 2019.

[25] S. B. Chodisetti, U. Gowthaman, P. K. Rai, A. Vidyarthi, N. Khan, and J. N. Agrewala, "Triggering through Toll-like receptor 2 limits chronically stimulated T-helper type 1 cells from undergoing exhaustion," Journal of Infectious Diseases, vol. 211, no. 3, pp. 486-496, 2015.

[26] M. Henao-Tamayo, S. M. Irwin, S. Shang, D. Ordway, and I. M. Orme, "T lymphocyte surface expression of exhaustion markers as biomarkers of the efficacy of chemotherapy for tuberculosis," Tuberculosis, vol. 91, no. 4, pp. 308-313, 2011. 